\title{
The Paštrovska House of the Montenegrin Coastal Area: Example of Sustainable Building in Traditional Architecture
}

\author{
Aleksandar KEKOVIĆ, Marjan PETROVIĆ, Aleksandra ĆURČIĆ
}

\begin{abstract}
The subject of this research is the Paštrovska house type of the Montenegrin coast. It is a part of the cultural heritage as a manifestation of individual housing, whose formation was affected by historical, sociological, climatic and other factors. It represents a collection of all the artifacts of material, social and spiritual culture, created throughout the centuries, to the present day. In this paper are analyzed climatic, topological and sociological factors as well as the used materials which affected the formation of this type of coastal house. The goal of this paper is to establish which of the mentioned factors had the greatest effect on this, in many respects, special kind of traditional sustainable architecture of the Adriatic coastline.
\end{abstract}

Keywords: architecture; climate; heritage; rural; sustainable

\section{INTRODUCTION}

Cultural heritage is a collection of all the artifacts of the material, social and spiritual culture, created through the centuries to the present day. These artifacts are a product of the creative endeavor of the people, and of each individual who contributed to raising the general cultural level of his community [1], [2].

In every vernacular architecture, there are specificities which are conditioned by the location, climate, materials available for construction, economic potential, historical circumstances and geographic position, all of which give rise to differences, i.e. to the creation of regional architectures [3-6].

In vernacular architecture, each house has its recognizable appearance and its characteristics, which could not be achieved through contemporary typization. This, in turn, leads to the conclusion that it is the result of centuries of craftsmanship experience (the individuality of each single craftsman); it is an adherence to the principle that in a specific area, only the houses made from the material available in that area can "thrive"; that only, or almost only, using these materials, can the make the simplest house, constructed from typical materials in a specific area, simultaneously fit into the ambient, and with its simplicity, functionality and used materials, provide a certain character, enhance the surroundings, the home and its owner - builder [7-10].

\section{STATE OF THE ART}

The Paštrovska house was named after the Paštrovska Mountain or after the clan of Paštrovići, a clan that has inhabited this area since ancient times. The Paštrovići are situated in middle part of the Montenegrin coast, which coincides with the present day Budva municipality. Located in the center of the Montenegro Adriatic coast, they border the Paštrovska Mountain in the north, Fig. 1 [11].

Paštrovići consist of 19 villages with 31 hamlets. The concept of a village comprises one or several groups of houses which are separate and constitute one geographic entity.
Each village has its own area, and most of them have an established contact with the coastline.

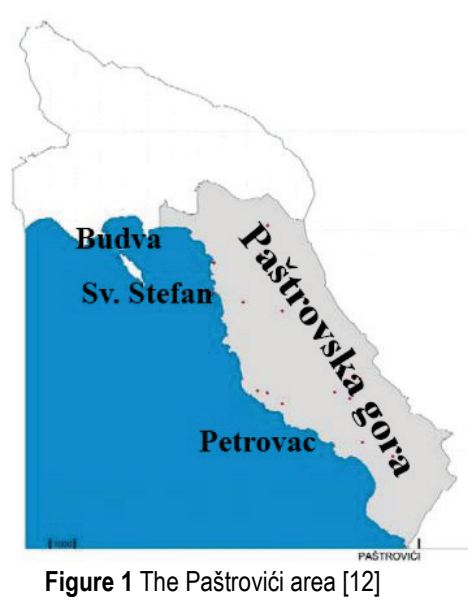

In terms of their position, the villages can be classified into two groups: coastal ones, located next to the seaside (among others, Pržno), and those in the so-called hinterland, at around $300 \mathrm{~m}$ a.s.l. (among others, Čelobrdo). The influences they were exposed to over time, and conditions related to their origin and location, provide an explanation for some of the differences in their structure and appearance [12].

In the existing research, the Paštrovska house is treated as an integral part of the coastal Dalmatian house, with some specific geographical and etymological differences characteristic of this type.

The Paštrovska house, as a manifestation of individual housing, was analyzed in professional and scientific research $[13,14]$ especially after the earthquake of 1979 .

Stanko Gaković [15] included field recordings in his work, establishing an extraordinary photo-documentation database, as well as an excellent analysis of the rows of the houses and a classification of the Paštrovici villages into mountainous and coastal ones.

Dušan Vuksanović [16] provided a comprehensive review of the traditional architecture of Montenegro and a presentation of the architecture in the Paštrovići region with a focus on the bioclimatic aspect of such architecture, all illustrated in examples. Nadežda Pešić - Maksimović [17], by analyzing the houses in Pržno and Rafailovići, 
pointed out the value of cultural heritage through the construction of the coastal Paštrovska house.

An anthropologic research of Paštrovići was provided in a paper by Jovan Vukmanović [18].

Rade Ratković and Vlado Duletić [19] stated that the basic aim of the sustainable development of the area of Čelobrdo, Fig. 2, is reflected in marking out the autochthonous village agglomerations (Čelobrdo, Marovići, Rustovo, Slanjina and Krute) and maximally preserving them, by providing authentic restoration and revitalization of all old houses, abandoned households, courtyards, streets and public spaces, with the removal of new buildings which with their architecture do not fit into the ambient of the old villages.

B. Gregovic [12] points out that the architecture of the Paštrovići settlements cannot be analyzed outside the spatial, temporal, climatic and social contexts. This conditioning is observable on every structural level in the settlement, from the group, to individual houses. It is precisely the spatial structure defined in these terms, the group or assembly of houses, that provides the grounds for the interpretation of the key terms characteristic of this type of architecture.

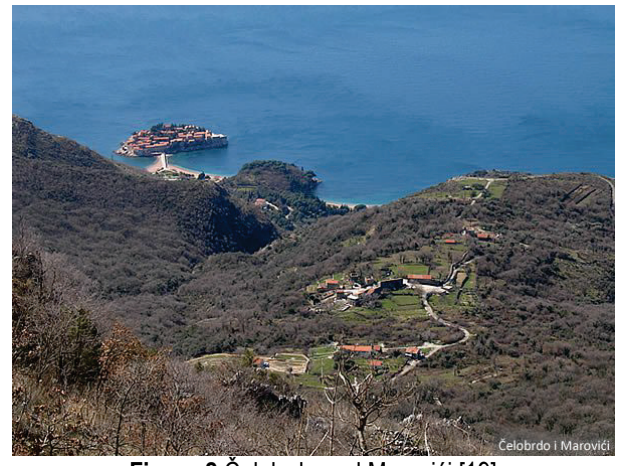

Figure 2 Celobrdo and Marovići [19]

Aleksandar Keković (Keković [20] pointed out that the Paštrovska house, which belongs to traditional architecture, is characterized by functionality and building on a human scale. Builders managed, through a simple architectonic expression, to incorporate all the necessary elements of sustainable design, taking care of every detail, proportion and measure.

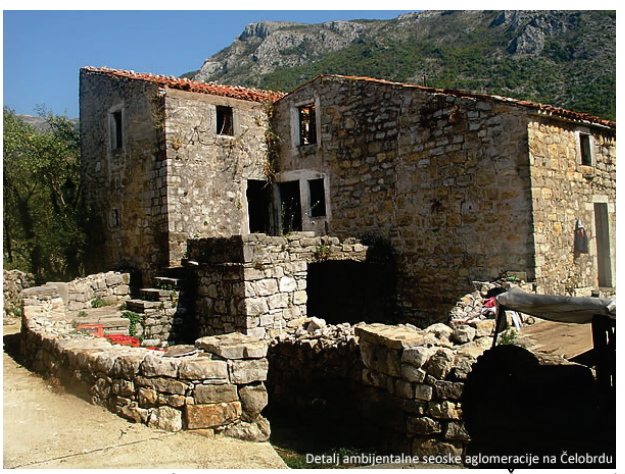

Figure 3 A detail of ambient rural agglomeration on Celobrdo [19]

The well-conceived and shaped space of the Paštrovska house, which fits into and is adapted to its surroundings, confirms that architecture based on functionality and well measured proportions can qualify as sustainable architectonic design [21], Fig. 3 and 4.

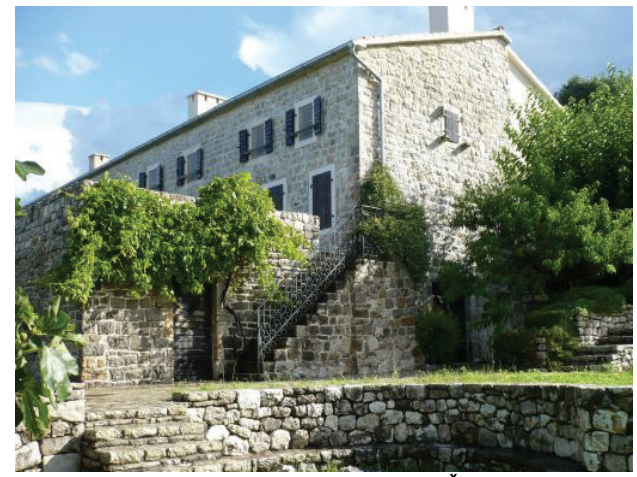

Figure $4 \mathrm{~A}$ residence in the village of Čelobrđe [19]

It can be concluded that construction in the past unconsciously followed the principles of sustainable building, specifically, that buildings were adapted to the environment or climate they belong to [22].

On the basis of the laid out climatic characteristics, construction material, structural systems, functional floor layout design etc., at a first glance it can be concluded that the Paštrovska house belongs to the Dalmatian type of vernacular architecture [22].

In organizational-functional sense, the Paštrovska house retained the basic vertical division resulting from the development of the house itself, so it remained the endemic example in the Adriatic area, and represents a good example for the study of house development along the entire Adriatic coastline [22].

\section{HISTORICAL DEVELOPMENT OF THE PAŠTROVSKA HOUSE}

The Slavs settle in this area between $8^{\text {th }}$ and $9^{\text {th }}$ centuries $\mathrm{AD}$, and it was populated by the Illyrians and Romans according to the "Ljetopis Popa Dukljanina" ("The annals of the Priest Duclean") [11]. Most of the settlements in the contemporary Paštrovići area were established at the end of the $14^{\text {th }}$ century [3].

In the Paštrovići area, one can observe three basic types of settlements, including:

- Budva and Petrovac as small towns

- Sveti Stefan as a village settlement with a special status and

- Village settlements, of coastal and mountainous character.

The best preserved original architecture of this area is nowadays found in the mountainous village settlements, because they retained all the properties of this simple architecture. In the coastal settlements, one can observe the influence from across the Adriatic.

In terms of the structure the Paštrovska house belongs to the type of coastal Boka Kotorska bay house [21], with the influences of the houses found in the hinterland [2224]. This house has a rectangular layout stemming from the original shape of an inclined shelter leaning on a rock. Under various influences, the house changes, by obtaining a wall on the north side which increased the volume of the building. 
In the later development of this type of the house, firstly another floor was added, and then another in the final phase. In front of the first floor, a terrace is formed, and it connects several structures. It is at the same time the roof for the entrance into the cellar (konoba) at the ground level. From the terrace level, which is sheltered with a pergola, one enters the residential part of the building, while the kitchen is on the top floor. This structure remained in the older houses and it represents a specific characteristic of this type of house, Fig. 5.
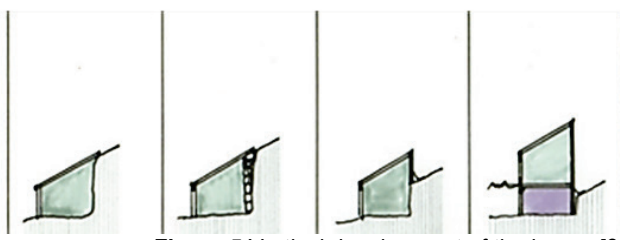

Figure 5 Vertical development of the house [22]

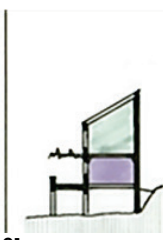

\section{FACTORS AFFECTING THE SUSTAINABILITY OF THE PAŠTROVSKA HOUSE}

A number of natural and social factors affected the development of the Paštrovska house:

- climate

- topology

- $\quad$ sociological factors

- used materials.

Each of the mentioned factors influenced the organizational, building - structural and technological aspect of the house.

The goal of this research is to, through analysis, determine the graded influence of all these previously mentioned factors on the sustainable building of the Paštrovska house in the traditional architecture of Montenegro.

\subsection{Climate}

The dominant factor which presented a condition for the development of the Paštrovska house is the climate. Even though the climate is Mediterranean, in the mountainous regions, in the winter season, a strong continental wind blows - the bura. The position of the house and the appearance of the façade are conditioned by the northern winds. Considering that the builders took this factor into account, as very important for determining the position of the Paštrovska house façade, proves that the awareness of sustainable building was already profoundly developed back then.

\subsubsection{Roof - Climate Effect}

The main dominant and characteristic element of the Paštrovska house architecture is the lean-to roof that is parallel to the gradient of the terrain. There are three basic reasons for the emergence of such a shape of the roof plane. The first reason is in the archetype taken from the original shelter which is convenient for its conforming to the contour line of the terrain and protecting from the north wind - the bura, by channeling the wind stream down the slope, Fig. 6 [12]. We find another reason for this shape of the roof in the drainage method, which drains the water along the entire length of the cornice, and there are no gutters - Fig. 7. Owing to such design on the gable side of the roof on the north side there is no moisture, so this design of the roof plane provides for the dryness of the konoba and the floors above it.
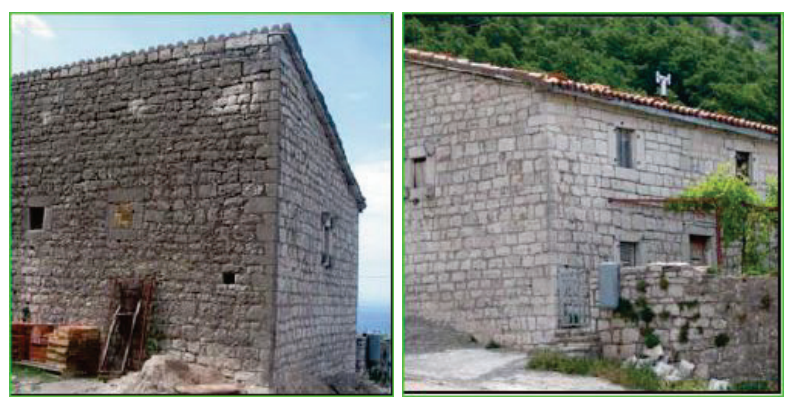

Figure 6 Paštrovska house lean-to roof [12]

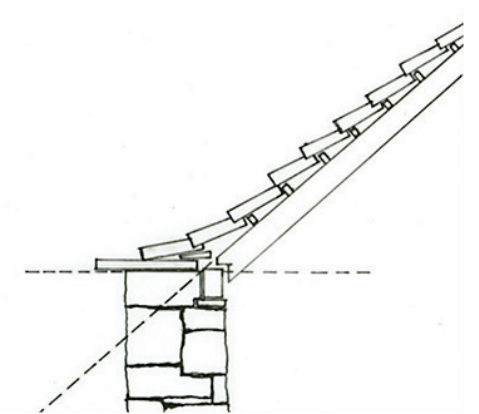

Figure 7 Transition of the roof through the wall plane [16]

\subsubsection{Façade - Climatic Impact}

By studying the façades, it can be noted that the lateral one, the ultimate façade in a row, is, as a rule, without any openings or with one or two openings of small dimensions, Fig. 8.

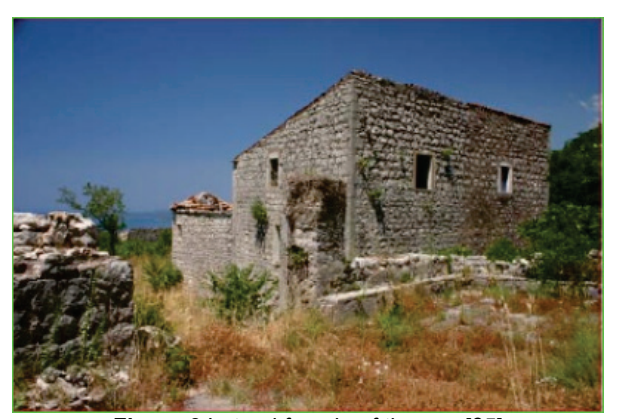

Figure 8 Lateral façade of the row [25]

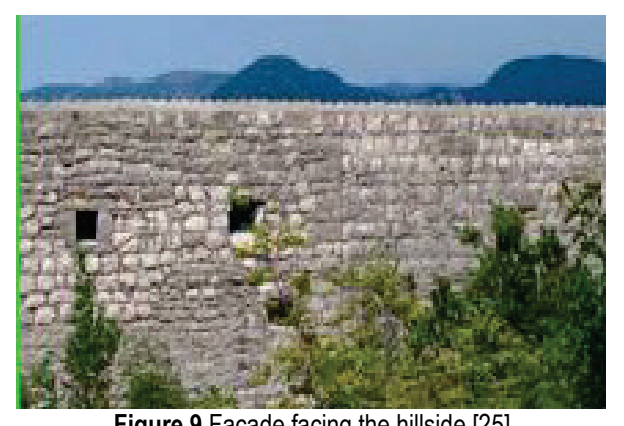

Figure 9 Façade facing the hillside [25]

The façades facing the hillside have very few openings. The reason for that is the protection of the inside 
of the house from the unfavorable effects of north winds, improved thermal comfort, and achieving better insulation, Fig. 9.

The most decorous façade is the one facing the downhill slope, oriented towards the sea. This façade supports the interior vertical division, so the ground floor is dominated by the entrance doors to the konobas. On the first floor there are terraces with pizhuns, door openings and larger window openings. On the second floor, there are small window openings right next to the cornice and the roof cover, Fig. 10 .

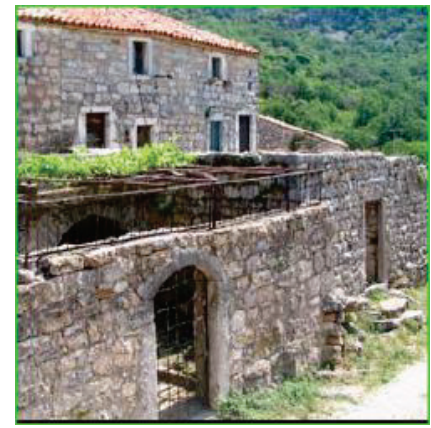

Figure 10 Façade facing the sea [19]

\subsubsection{Windows - Climate Effects}

Window openings have small dimensions (each individual opening is clearly visible), and they are of different sizes. The window size was conditioned by the technical ability to make openings in the stone walls, although small windows are justifiable in the summer heat conditions because they reduce the amount of light and heat entering the rooms. As was already mentioned, most of the openings are located on the front side of the house, and make up only $10-15 \%$ of the façade surface, which is a consequence of the functional orientation, and opens the house towards the bottom of the hill in order to control the property and provide beautiful vistas. Apart from the need for a good southern orientation, control of the property and vistas of the sea, the openings conceived in this way provide good protection by means of excessive insolation, especially in the summer season.
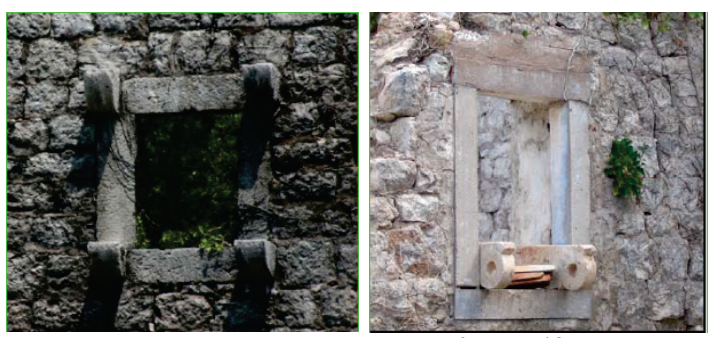

Figure 11 Windows with stone frames [12]

All the openings are built using square stone frames, Fig. 11, whereby the window frames are made of one slab of stone, while the door frames were built of two or three stone segments.

The construction of doors rarely features an arch lintel hewn from one stone piece, or an arch built up of several elements. The stone door frame is always in the wall plane.

The windows are sometimes closed only using wooden

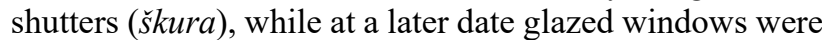
used as well, Fig 12a.
Just like in the Dalmatian house, there are stone consoles on the windows of the Paštrovska house, Fig. 12b.
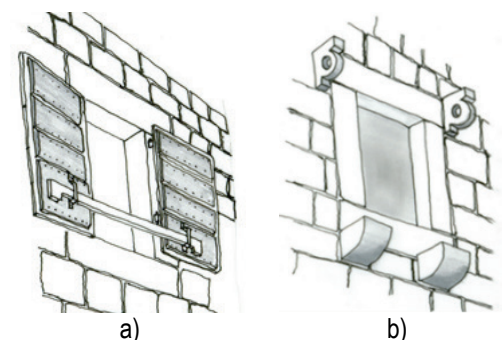

b)

Figure 12 a) Window double wooden shutters [16], b) Top stone consoleauriculi [16]

The upper consoles, "ears" (auriculi) are at the level of the window lintel, and they have circular holes used for holding a wooden bar for hanging a screen - curtain. The screen - curtain is used for shading and screening, preventing anyone from looking inside. What is especially interesting is the function of the soaked linen - curtains, which in the summer months, due to evaporation, are used for cooling, as a sort of primitive air conditioning [22].

The lower consoles, "teeth" (dentes), are the lower horizontal window frame, used for installing a board for drying farming products.

Doors are massive, wooden and mostly single-winged, while at a later period, double-winged massive doors were also installed.

\subsubsection{Adaptation of the Interior Function of Space to Climatic Conditions}

The house has relatively small dimensions $5 \times 6-7 \mathrm{~m}$, and each floor consists of one room. In the cellar there is a konoba for keeping food and animals, on the ground floor there is a sleeping area, while the attic accommodates a kitchen - "kužina sa ognjištem" (kitchen with a fireplace).

The entrance to the house and the communication to the living area are on the first floor, while communication was previously realized through the konoba via internal wooden stairs. The first floor is accessed directly from the terrace. The second floor is accessed via a steep wooden indoor staircase.

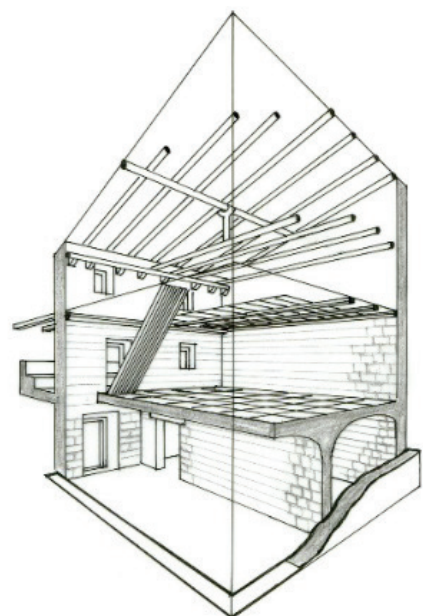

Figure 13 Architectonic- structural composition of the Paštrovska house [22]

The courtyard area and the konoba are connected with the first floor via an external stone staircase. At the level of 
the first floor there is a stone terrace which matches the length of the entire row.

The cellar functions as a basement floor and was previously used for keeping livestock and storing products.

The ground floor is used for rest and sleeping.

As opposed to most houses, in the loft there is a kitchen. This specific trait resulted from the insertion of new floors so the kitchen area is in the loft, and not as it is usual on the lower floor, Fig. 13.

\subsection{Topology}

In the Dinaric littoral, village settlements are most often to be found on the boundary line between sedimentary facies and limestone. This area is a point of contact between the slopes and arable land, and the limestone rocks [17]. Considering that sloped terrains dominate this area, the response to such topographic conditions in terms of the spatial matrix is twofold:

1) Either the spatial matrix is developed parallel to the contour lines, which necessitated the construction of small or long rows of houses which represent the most common type of construction.

2) Or, the spatial matrix is developed perpendicular to the contour lines which results in cascades, streets, which is a very rare case. Depending on the distance of the settlements from the sea, where the main communications are, the villages are either compact or loosely built, Fig. 14.

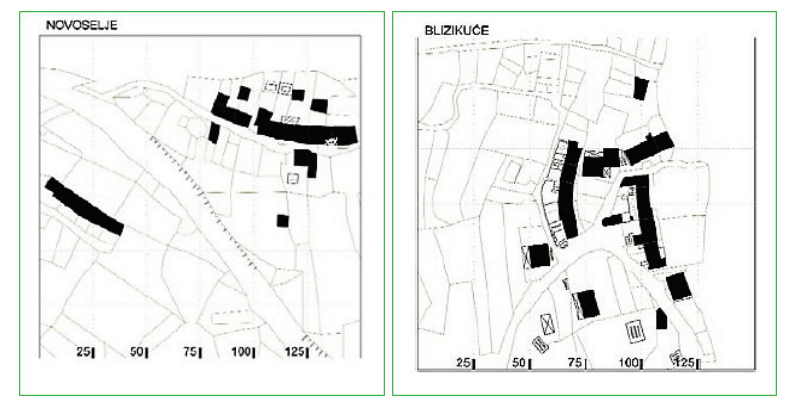

Figure 14 Compact and loose type villages [12]

In the Paštrovići clan area, one may observe the arrangement of settlements in specific elevation ranges, which corresponds to the configuration of the terrain below the steep sides and above small plateaus and small farming fields.

The row of houses is either straight or mildly curved, following the terrain configuration. The number of houses in a row ranges between 4 and 8 [12]. The houses in a row have the same height and cross-sections, and are covered by one roof plane with a common ridge. Such a manner of construction accomplishes rationality, cost and energy efficiency, and in architectonic terms, it provides a single silhouette in space. In the compact group of mutually separated hamlets, which as a rule lie on the same contour line, the dominant form is a row of houses belonging to close relatives, with common walls.

The lack of security for one's property at the time when these villages emerged, and the need to use the land in a rational manner, caused the formation of rows of houses which are a dominant form of village organization.

Villages formed in this manner, compact in their structure, create the impression that they are a specific pseudo - urban form [12].
Therefore, it can be concluded that the rows represent a form of sustainable development, in the case of the Paštrovska house, because:

1) They adapt to the terrain, and affect in the terrain slope and contour lines, so that there would be fewer interventions in space, i.e. that construction would be easier.

2) By forming the rows of houses, mostly towards one side of the street, a favorable microclimate is facilitated, especially in the summer season, because it does not obstruct the air flow, which as a rule does not appear on other locations in the Mediterranean.

3) The Paštrovska houses in a row are internally connected, because at the ground level there is the terrace that connects them, Fig. 15a and 15b, and at the basement level, they are connection for emergency situations, for defensive purposes. Such a formation of the walls caused a reduction of heat loss, because there are fewer outer façades.

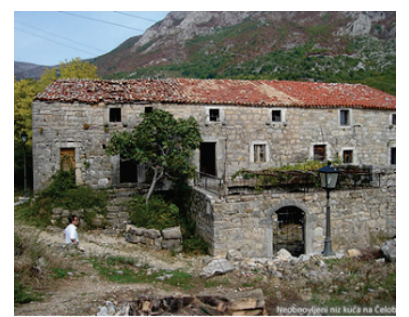

a)

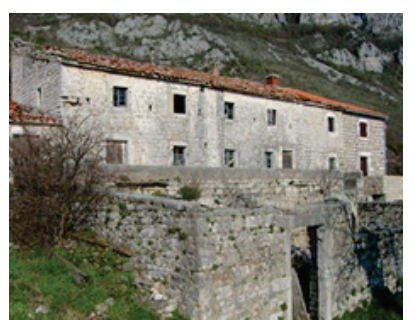

b)
Figure 15 a) Row in Čelobrđe [19], b) Row of the Paštrovska house [19]

\subsection{Sociological Aspect of Development}

What is meant by the sociological aspect of the development of the Paštrovska house is that the organization of such a house to a great extent emerged from social-historical circumstances.

After the disintegration of the feudal order of emperor Dušan's empire, there was a gradual regression to tribal and clan communities, which resulted in the organization and division of society into clans, phratries and tribes, which is quite characteristic of the area of present-day Montenegro, and therefore the area of Paštrovići.

Such an organization and division, primarily the division into phratries, caused a more efficient protection of cultural - historical and national heritage from foreign influences, both from the east (Turks), and from the west (Venetians and Austrians). Even though one aspect of this process is a sort of a developmental decadence, its primary goal was the preservation of historical memory on the one hand, and on the other, purely biological protection of the survival of the nuclear family.

Organizing themselves in the strictly patriarchal manner of phratries and tribes, such communities guarded their identity, and rarely mixed with other phratries, except in matters of marriage.

In this way, the created villages belonged almost solely to a single phratry, and everyone was kin, which made for a better connected community, and made it easier to defend it from the enemy, who, unfortunately was not always foreign. There were conflicts between the phratries and tribes. For this reason, the houses were packed closely together, and rows were formed so that it would be easier to defend them, especially if they were located on 
inaccessible terrain, such as the Paštrovska mountain terrain and the hinterland of the municipality of Budva.

\subsubsection{Orientation - Sociological and Climatic Aspects}

The orientation of the Paštrovska house towards the sea and access roads provided a good vista and a timely spotting of enemy incursions, Fig. 16.

The unobstructed vista represents an additional quality of the house position, facing the sea, and its southern orientation; this makes maximum use of the sunrays and air coming from the sea which contains medicinal minerals in the aerosol and contributes to the health of the dwellers in the Paštrovska house type.

An open terrace under the porch provides a longer outdoor stay in the summer season, which has a beneficial effect on human health and prolongs life.

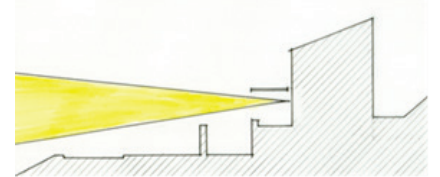

Figure 16 The façade of the Paštrovska house facing the slope in the direction of the sea, fields and access roads [22]

\subsubsection{Terraces - Sociological Aspect}

In the Paštrovska house, the terrace is situated in front of the house on the level of the first floor, it usually matches the width of the house front, or can be slightly narrower. The depths of the terraces vary and depend on the conditions which dictate the position of the house on the lot of land, and position within the system (group). The terrace provides direct access to the housing space on the first floor. The terrace is elevated on a stone vault, or possibly on two or three vaults in the case of a larger surface area.

In most cases, access from the courtyard to the terrace itself is realized by an external stone staircase, Fig. 17, but it can be a public area, i.e. a semi-public group with a concentration of houses and a formation of space resembling urban structures (Tudorovići and the Rafailovići).

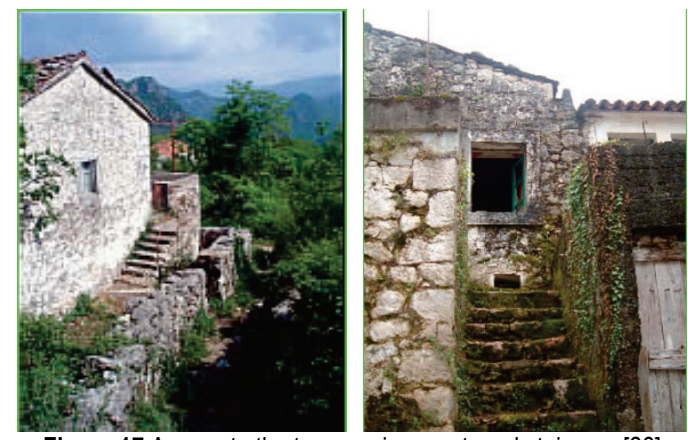

Figure 17 Access to the terrace via an external staircase [26]

The terrace is paved with rectangular flagstones. On its periphery is a parapet which is shaped to serve as a seat (bench), Fig. 18, and the bench backrests are mildly inclined from the inside downwards, formed using stone tiles.
Above the terrace, in most cases, there is a pergola with vines, providing shade in the summer and defining the space of the terrace with its canopy, Fig. 19.

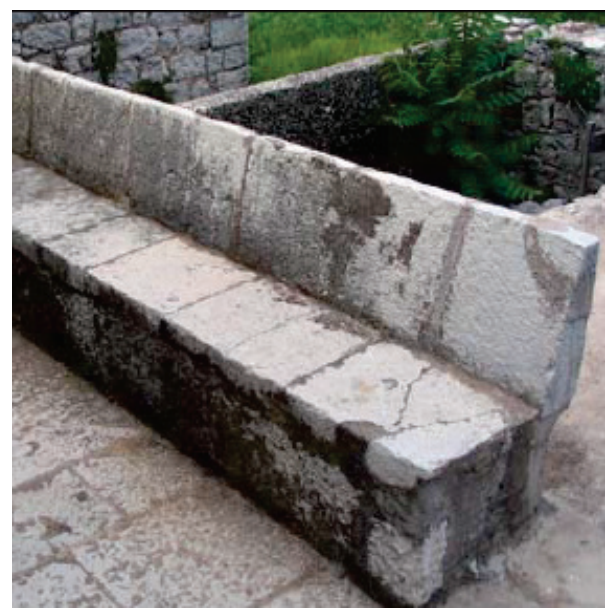

Figure 18 Bench [12]

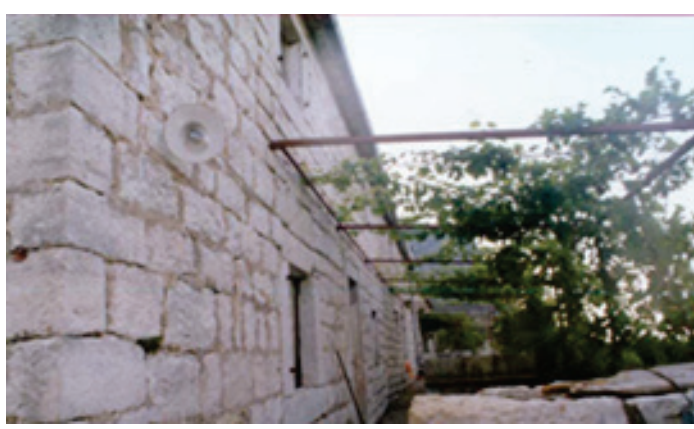

Figure 19 Terrace - pižun [22]

The terrace simultaneously represents an extension of the living quarters during the summer (6 months), providing a sort of a summer living room [14]. It is an integral part of the Mediterranean tradition that life takes place outdoors for more than half a year. It is a mainstay of social life in the house and outside. Guests are entertained there, business is conducted, and the property and access roads from the sea are monitored. Therefore, in addition to being an open living room, it is also a public area. Because the terrace can be used both as a private and public space, it can be noted that on the terrace areas, the first primitive elements of the urban exterior were formed (precursors of street furniture), including: a bench, pergola - seasonal covering of an area. All this represents an experiential materialization of building heritage, adapted to climatic conditions.

\subsubsection{Courtyard - Sociological Aspect}

Most of the houses in the area of Paštrovići have a courtyard enclosed with a high garden wall, Fig. 20.

The courtyards are of various sizes, and a surface area of a courtyard most often corresponds to the area of a house. Due to the high wall, which reaches the height of the first floor, the fenced courtyard is reminiscent of an atrium, although it is not one, because the residential rooms do not open directly towards the courtyard, but towards the terrace at the level of the first floor.

The courtyard is used for keeping livestock and poultry, below the terrace or in the konoba, and one part of 
the courtyard is used to store firewood. The konoba was to the most part used as a larder for storing food, olive oil and wine. From the courtyard, a stone staircase leads to the first-floor level, i.e. terrace.

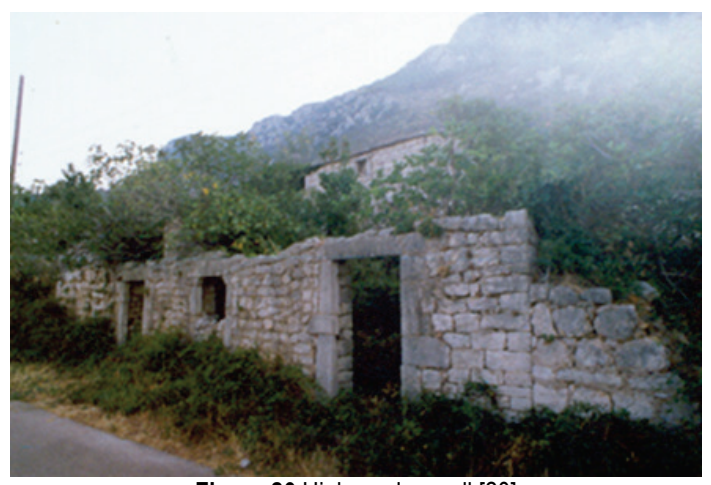

Figure 20 High garden wall [20]

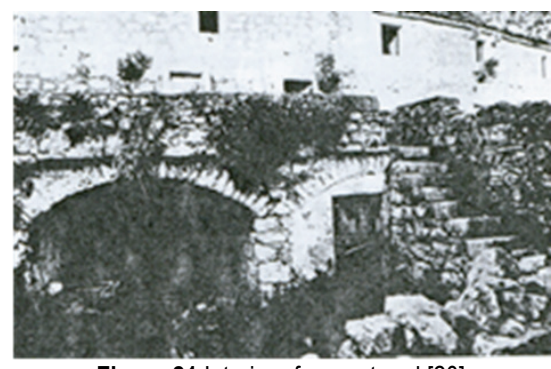

Figure 21 Interior of a courtyard [20]

The entrance gate to the courtyard has either a flat or arched lintel, Fig. 21. The width of the gate is always over $1 \mathrm{~m}$, because it was necessary to let a supply horse with a load through. All gate doors are made of wood, Fig. 22.

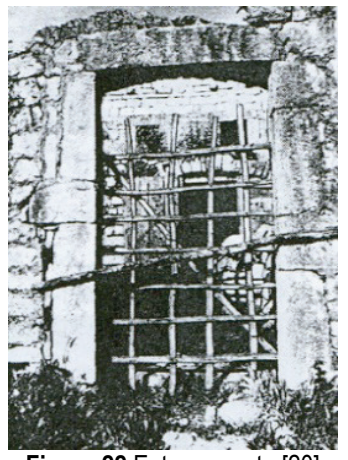

Figure 22 Entrance gate [20]

\section{USED MATERILAS}

In the coastal area, stone undoubtedly represents a recognizable element of the regional architecture.

The basic material for construction of the Paštrovska house is hewn stone. The floors between the first and the second floor are made of wood, while the roof is covered with "kanalica" S-tiles. The roof structure and the floors are made of wood. The stone roof over the konoba is paved with flagstones. The roof is an inclined, lean-to roof, the reason being that timber is a sparse resource in this area and is rarely used, and when it is inevitable and in a most rational way. The second reason is reflected in the fact that the lean-to roof is relatively easy to construct as it is supported by the front and rear façade walls which is by far simpler for construction than the gable roof structures, Fig. 23.
Finally, it can be said that such method of construction of roof planes is founded on the archetype modified in time.

The roof cover was the "kanalica" S-tile, which was initially procured from Dubrovnik. Later it was produced in Tivat and Krtole as well as in Kaluđerica in the Paštrovići region, making it readily available. Thus, it can be considered a local material (Keković, 2001). Rainwater running down the gable walls is prevented by placing tiles in the ulterior rows upside-down. Since there are no gutters, at the level of the cornice, the roof cover is left projecting $15-20 \mathrm{~cm}$ to resemble eaves, Fig. 24

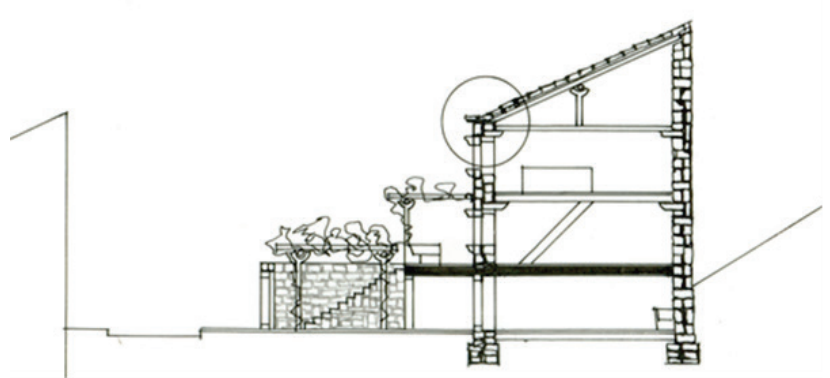

Figure 23 Cross section - support of the roof structure [14]

After finishing the structure, for the needs of division of the family, partition walls were made of wattle and wood lathing. The interior staircase which connects the first floor and the loft was made of wood.

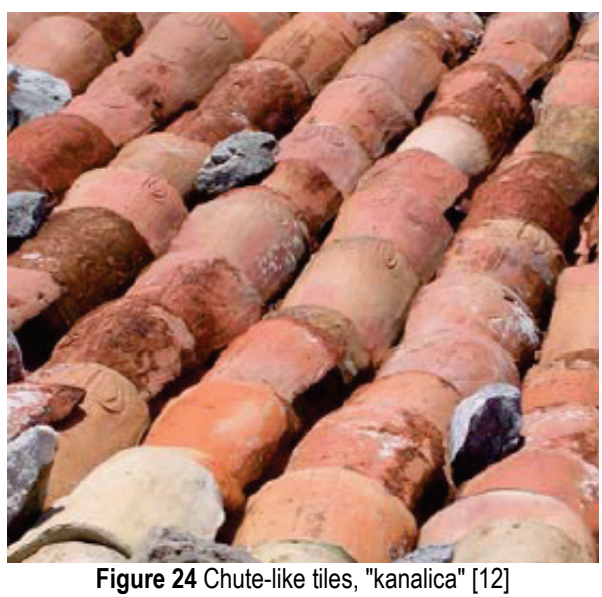

The structure directly depends on the available material and craftsmanship of the builders. An important role was played by the local tradition, influenced by some temporary foreign impulses.

Older and newer houses differ in terms of the fineness of masonry stone dressing, the stone-laying method, wallthickness and the way the walls were positioned on the ground. The single-storey older houses were made of dry walls of coarsely dressed stone. In the case of the newer houses, with several floors, such as the Paštrovska house, they were made of hewn stone. The walls have two faces, 50 to $80 \mathrm{~cm}$ thick, with almost level, horizontal joints. The face of the wall is made of selected limestone pieces, cut out from larger stone blocks, regularly hewn and finely dressed. They are joined using lime, or lime mortar, while the core of the wall is filled with crushed and small stone riprap. 
For the construction of the façade wall, which includes a row of 6 to 8 houses, hewn stone was used, which is slightly coarser in the house cellar. Special attention was given to the construction of window and door openings, which are framed with large stone pieces, finely dressed.

The laying of stone walls, regardless of the period of construction and quality of the stone dressing, is characterized by the fine craftsmanship of the interior and exterior wall faces, which are made of selected and carefully joined stone.

There is no horizontal waterproofing, since it is not necessary because the buildings were never built on arable topsoil in this rocky region.

The roof and floor structures are made of timber. The floor structure is composed of joists resting on the opposite walls and the floorboards directly nailed to the joists. In the case of larger spans, there are additional crossbeam and timber columns. As for the way the joists are rested on the stone walls, there are two variants:

1) The holes are left in the walls during laying, so that the joists can be inserted later.

2) The most common way of supporting the joists is making a stone console which serves as a support point for the joints. This is the most practical solution, because it facilitates easy replacement of decayed timbers.

\section{CONCLUSIONS}

Based on the analysis of the factors which influenced the sustainable building of traditional architecture of the Paštrovska house, it can be concluded that the dominant factor is the climate, for the following reasons:

1) The lean-to roof plane built parallel to the slope gradient protects the house from the wind effects, by not presenting a barrier to the wind flowing down the slope.

2) The limitations resulted from the construction of the lean-to roof structure caused the decreased depth of the house, resulting in an easier illumination of the rooms, through the small openings on the south façade.

3) The reason for few openings on the hillside façade is to protect the inside of the house from the unfavorable effects of north winds, to improve thermal comfort and achieve better insulation. At the same time, it is a justifiable solution for the summer climate because it prevents excessive light and heat from entering the rooms.

4) The upper consoles on the windows with circular holes make it possible to hang up screens which serve to provide shade and privacy. What is particularly interesting is the function of the soaked linen - curtain, which during the summer months, due to evaporation, is used for cooling, as a sort of primitive air conditioning.

5) The house's southern orientation makes maximum use of the sunrays and air coming from the sea, which contains medicinal minerals in the aerosol and contributes to the health of the dwellers in the Paštrovska house type.

6) By placing the kitchen in the loft, the efficient ventilation of the kitchen was provided during the summer months, and the heating of the rooms on the first floors was avoided. In the winter period, it was used for smoking meat, and the smoke also provided disinfection; thus, it can be concluded that the unusual position of the kitchen on the last floor has its environmental and functional justification.
7) The terrace simultaneously represents an extension of the living quarters during the summer (6 months), and is an integral part of the Mediterranean tradition in which life takes place outdoors for more than half a year. All this represents an experiential materialization of building heritage, adapted to climatic conditions.

8) An open terrace under the porch provides longer outdoor stay in the summer season, which has a beneficial effect on human health and prolongs life.

The following factor, in terms of importance, that affected the development of the Paštrovska house is topology. As a result of topology, rows of houses were formed. They represent a form of sustainable building for the Paštrovska house because:

1) They adapt to the terrain, and they factor in the terrain slope and contour lines, so that there would be fewer interventions in space, i.e. the construction would be easier. 2) By forming rows of houses, mostly towards one side of the street, a favorable microclimate is facilitated, especially in the summer season, because it does not obstruct the air flow which as a rule does not appear on other locations in the Mediterranean.

3) Paštrovska houses built in a row are internally connected, because at ground level it is the terrace that connects the homes, and at the basement level, they are connected for emergency situations, for defensive purposes. The formations of the walls resulted in a reduction of heat loss, because there are fewer outer façades.

The third influential factor is the sociological aspect: 1) An organization and division into phratries caused the grouping of phratries for the more efficient protection of cultural - historical and national heritage from foreign influences. Even though one aspect of this process is a sort of developmental decadence, its primary goal was the preservation of historical memory on the one hand, and on the other hand a purely biological protection of the nuclear family. In this way, the created villages belonged almost solely to a single phratry, and everyone was kin, which better connected the community and made it easier to defend it from the enemy.

2) The orientation of the Paštrovska house towards the sea and access roads provided a good vista and a timely spotting of enemy incursions.

3) Most of the openings are located on the front side of the house, and make up only $10-15 \%$ of the façade surface, which is a consequence of the functional orientation and of opening the house towards the bottom of the hill, in order to control the property and have beautiful vistas.

4) The terrace is important from the sociological viewpoint. It is a mainstay of social life in the house and outside. Guests are entertained there, business is conducted, and the property and access roads from the sea are monitored. So in addition to being an open living room, it is also a public area. Because the terrace is used both as a private and public space, it can be noted that in the terrace areas, the first primitive elements of urban exterior were formed (precursors of street furniture), including: a bench, pergola - seasonal covering of an area.

The used material is the last influential factor which affects the formation of the Paštrovska house, reflected in the use of available material such as stone and timber for construction. Stone is a material used from ancient times, 
and builders were acquainted with its properties and application. The material itself has excellent thermal accumulation properties which makes it suitable for this area. Timber, as the other available material, provided the construction of an adequate roof, functionally adapted primarily to climatic conditions.

It is the general conclusion that the people from these parts, through generations, using experience acquired through several centuries of construction, developed skills to build as it best suited them in the given time, terrain and based on their economic potential, without destroying the harmony existing between them and the environment. They built buildings to suit their own needs, which leads us to the conclusion that the Paštrovska house of the Montenegrin coast is an example of sustainable development in traditional architecture.

It would be advisable nowadays for the architects and builders to design and build contemporary sustainable buildings according to human measures, while using the inherited patterns of traditional way of buildings and locally available material and observing climatic conditions and contours of the terrain.

\section{REFERENCES}

[1] Kojić, B. (1949). Staragradska i seoska arhitktura u Srbiji. Beograd, Srbija: Prosveta.

[2] Gabrijan, D. (1973). Razvojni put naše savremene kuće. Beograd, Srbija: Građevinska knjiga.

[3] Kojić, B. (1957). Seoska arhitektura u Paštrovićima. Glasnik Etnografskog instituta SANU, IV-VI, 225-240.

[4] Cvijić. J. (1987). Balkansko poluostrvo i Južnoslovenski narodi, Sabrana dela. Beograd, Srbija: SANU, Književne novine, Zavod za udžbenike i nastavna sredstva.

[5] Tomović, S., Stanišić, P., \& Kadi, S. (2018). Data Mining Approach in Climate Classification and Climate Network Construction - Case Study Montenegro. Technical Gazette, 25(4), 1037-1043. https://doi.org/10.17559/TV-20160913205831

[6] Mrowczynska, M., Laczak, A., Bazan-Krzywoszanska, A., \& Skiba, M. (2018). Improving Energy Efficiency with the Risk of Investment of Reference to Urban Development of ZielonaGóra. Technical Gazette, 25(3), 916-922. https://doi.org/10.17559/TV-20161212120336

[7] Deroko, A. (1968). Narodno graditeljstvo 1. Beograd, Srbija: Odeljenje društveni hnauka NS 20, Srpska akademija nauka.

[8] Findrik, R. (1980). Prilozi poznavanju organizacije stambenog prostora u narodnom graditeljstvu sela. Beograd, Srbija: Arhitektonski fakultet u Beogradu.

[9] Shahran, A., Reba, D., \& Krklješ, M. (2017). Thermal comfort, adaptability and sustainability of vernacular single family houses in Libya. Technical Gazette, 24(6), 19591968. https://doi.org/10.17559/TV-20160412221515

[10] Poropat, A. (2017). Family house courtyard in the context of sustainable arrangement. Technical Gazette, 24(2), 513-524. https://doi.org/10.17559/TV-20160402125822

[11] Keković, A. (1999). Povratak tradiciji Paštrovske kuće. Zbornik radova Komunikacije 1999: Urbano i arhitektonsko nasleđe u trećem milenijumu, CEP Beograd, MONTECEP Kotor.

[12] Gregović, B. (2007). Paštrovska kuća. Contemporary expression of traditional houses in Montenegro.

[13] Šišić, F. (1928). Ljetopis popa Dukljanina. Beograd-Zagreb: SKA.

[14] Kojić, B. (1973). Seoska arhitektura i rurizam - teorija $i$ elementi. Beograd, Srbija: Građevinska knjiga.
[15] Gaković, S. (1979). Paštrovska kuća.Beograd, Srbija: Istraživanje za potrebe prostornog plana Opštine Budva, Beograd projekat - centar za planiranje urbanog razvoja

[16] Vuksanović. D. (1998). Tradicionalna arhitektura Crne Gore $i$ bioklimatuzam. Beograd, Srbija: Zadužbina Andrejević.

[17] Pešić-Maksimović, N. (1967). Pržno i Rafailovići. Cetinje, Crna Gora: Republički zavod za zaštitu spomenika kulture SR Crne Gore.

[18] Vukmanović, J. (1960). Paštrovići - Antropo-geografsko ispitivanje. Cetinje.

[19] Ratković, R. \& Duletić, V. (2014).Smjernice za održivi razvoj poručja Čelobrda ko bisera ruralnog turizma. Sveti Stefan / Crna Gora: Portal Montenegrina, Kulturna kapija Crne Gore.

[20] Keković, A. (2001). The house of Pastrovici: universal in traditional. Facta Universitates - Architecture and Civil Engineering, 2(3), 193-208.

[21] Keković, A. (2001). Predlog arhitektonsko-urbanističkog projekta revitalizacije Paštrovskih naselja. Zbornik radova "Stanovanje ka trećem milenijumu", Edicija Arhitektonika Arhitektonski fakultet Univerziteta u Beogradu.

[22] Keković, A. (2003). Valorizovanje Paštrovkse kuće kao posebnog tipa primorske kuće u našem arhitektonskom nasleđu, Magistarska teza, Građevinsko - arhitektonski fakultet, Univerzitet u Nišu.

[23] Petrović, Z. (1957). Selo i seoska kuća u Boki Kotorskoj. Zbornik Arhitektonskog fakulteta 3, (knjiga 1956/57) Univerzitet u Beogradu.

[24] Đurović, G. (1980). Naselje i kuće Tivatskog zaliva. Beograd, Srbija: Centar za planiranje urbanog razvoja.

[25] Architectural atlas of Montenegro. (2006). Crna Gora: Ministarstvo za ekonomski razvoj Crne Gore.

[26] Stamatović, S., Šuković, D., \& Tomanović, Z. (2007). Crmnica (crmnička "Nahija"). Contemporary expression of traditional houses in Montenegro.

\section{Contact information:}

Aleksandar KEKOVIĆ, Associate Professor, PhD

The Faculty of Civil Engineering and Architecture, University of Niš,

Aleksandra Medvedeva st., 14,

18000 Niš, R. Serbia

E-mail: kekovic.aleksandar@gmail.com

Marjan PETROVIĆ, PhD student

The Faculty of Civil Engineering and Architecture,

University of NiŠ

Aleksandra Medvedeva st., 14,

18000 Niš, R. Serbia

E-mail: petrovicmarjan77@gmail.com

Aleksandra ĆURČIĆ, PhD student

The Faculty of Civil Engineering and Architecture,

University of Niš

Aleksandra Medvedeva st., 14,

18000 Niš, R. Serbia

(Phone: +38118588202; fax: +38118588202)

E-mail: ajkiro94@gmail.com 